\title{
CAMBRIAN-ORDOVICIAN BOUNDARY BEDS IN THE PAKRI CAPE SECTION, NW ESTONIA
}

\author{
Kaisa MENS ${ }^{a}$, Heljo HEINSALU ${ }^{a}$, Kalmer JEGONJAN ${ }^{b}$, Tiia KURVITS ${ }^{b}$, \\ Ivar PUURA ${ }^{\mathrm{a}, \mathrm{c}}$, and Viive VIIRA ${ }^{\mathrm{a}}$
}

a Geoloogia Instituut (Institute of Geology), Estonia pst. 7, EE-0001 Tallinn, Eesti (Estonia)

b Tartu Ulikooli geoloogia instituut (Institute of Geology, University of Tartu), Vanemuise 46, EE-2400 Tartu, Eesti (Estonia)

c Institutionen för Geovetenskap, Uppsala Universitet (Institute of Earth Sciences, Uppsala University), Dept. of Historical Geology and Palaeontology, Norbyvägen 22, S-75236 Uppsala, Sverige (Sweden)

Presented by D. Kaljo

Received 4 May 1995, accepted 10 October 1995

Abstract. For obtaining new information on the biostratigraphy and mineralogy of the Pakerort Stage in its type area, the Cambrian-Ordovician sequence in the Pakri Cape section (previously known as Pakerort) located $1 \mathrm{~km}$ southeast of the promontory of the Pakri Peninsula, NW Estonia, is described.

The varigrained quartzose sandstones of the Kallavere Formation, representing a disputable part of the Cambrian-Ordovician boundary interval in Estonia, lie discontinuously on the sand- and siltstones of the Lower Cambrian Tiskre Formation. Lithological subdivisions of the Kallavere Formation, the Maardu and Suurjōgi members, differ in the structure and grain size, but show close mineral composition. The biostratigraphical age can be established only for the lower part of the Maardu Member which belongs to the Cordylodus proavus conodont Zone; the $C$. andresi Zone is apparently missing. Younger conodont zones cannot be established with confidence owing to scarcity and poor preservation of conodont elements. The overlying Türisalu Formation yields Rhabdinopora flabelliformis and $R$. cf. desmograptoides.

Key words: Upper Cambrian, Lower Ordovician, Kallavere Formation, Pakerort Stage, conodonts, brachiopods, mineralogy, Pakri Peninsula, Estonia.

\section{INTRODUCTION}

The westernmost exposures of the Cambrian-Ordovician boundary beds in Estonia are located on the Pakri Peninsula. Raymond (1916) outlined the modern stratigraphy of these beds by defining the Packerort Formation comprising Obolus Sandstone and Dictyonema Shale, with the type section near the lighthouse, close to the promontory of the Pakri Peninsula. Further, with the introduction of regional stages in the East Baltic stratigraphy, the Pakerort Stage having about the same stratigraphical extent, was introduced (Мююрисепп, 1958, 1960). While the debate on the Ordovician lower boundary is continuing, the base of the Cordylodus andresi conodont Zone is referred to as the tentative base of the Pakerort Stage (Männil, 1990).

Current research outside the type area has resulted in the biostratigraphical zonation of the Cambrian-Ordovician boundary beds in Estonia and adjacent areas (Kaljo et al., 1986, 1988; Попов \& Хазанович, 1989; Mens et al., 1993; Puura \& Holmer, 1993) and in detailed mineralogical 
studies of selected sections (Хейнсалу et al., 1987; Mens et al., 1989). These data provide a valuable basis for interpreting the CambrianOrdovician stratigraphy on the Pakri Peninsula, the type area of the Pakerort Stage. Inaccessible for more than 30 years, this area has been available for geological studies since August, 1993, after the withdrawal of the Soviet troops from the navy base at Paldiski.

The present paper describes a coastal section on the Pakri Peninsula which was sampled in September, 1993. The mineralogy of very fine sand and clay fraction was examined by K. Mens and T. Kurvits, respectively. the grain size and distribution of skeletal fragments by $\mathrm{H}$. Heinsalu, and the conodonts by K. Jegonjan and V. Viira. I. Puura studied the lingulate brachiopods and compiled the biostratigraphical review.

\title{
DESCRIPTION OF THE SECTION
}

The section studied is located in the northeastern klint wall approximately $1 \mathrm{~km}$ southeast of the promontory (Fig. 1). In the surroundings, the total thickness of the exposed Cambrian-Ordovician bedrock sequence, ranging from the sandstones of the Lower Cambrian Tiskre Formation to the carbonate rocks of the Middle Ordovician Uhaku Stage, is from 20 to $24 \mathrm{~m}$. The Cambrian-Ordovician boundary beds are represented by the $4 \mathrm{~m}$ thick Kallavere Formation (Obolus Sandstone; Fig. 1) which is overlain by the Türisalu Formation (Dictyonema Shale). The description is given from base to top.

\section{Lower Cambrian \\ Tiskre Formation ( $E_{1}$ ts)}

Light grey sandy siltstones with interbeds of shaly siltstones and clays. The topmost $0.1-0.2 \mathrm{~m}$ are strongly pyritized and now brownish-yellow due to oxidation of some of pyrite to jarosite. Ripple marks are common in the upper part of the Tiskre Formation. Its upper surface is uneven and deeply pitted, rarely smooth. The contact between the Tiskre and Kallavere formations is sharp and marked by the appearance of kerogenous shale and phosphatic shell fragments of lingulate brachiopods. Exposed thickness up to $4 \mathrm{~m}$.

\section{Upper Cambrian-Lower Ordovician}

\author{
Pakerort Stage \\ Kallavere Formation \\ Maardu Member $\left(\mathrm{E}_{3}-\mathrm{O}_{1} \mathrm{kl} M\right)$
}

Bed 1. Dark brown kerogenous shale with very thin quartzose fineand very fine-grained sandstone interbeds at the base. Upwards the sandy interbeds become thicker and more frequent (sample 3). Occasionally there occur boulders derived from the underlying Tiskre Formation. Thin lenses of basal conglomerate are exposed about 200-300 m eastward (description in Nemliher \& Puura, 1996). The lenses contain shell fragments of lingulate brachiopods, mostly from the genus Ungula. Thickness $0.1-0.25 \mathrm{~m}$.

Bed 2. Yellowish-grey quartzose fine- and very fine-grained sandstone, with horizontal and wavy irregular dark kerogenous shale interbeds up to some $\mathrm{cm}$ in thickness. The ratio of sandstone and shale layers is $2: 1$ (samples 4-6). The sandstone contains only scarce phosphatic skeletal fragments of lingulate brachiopods. Thickness $0.5-0.65 \mathrm{~m}$. 
Bed 3. Greyish-yellow quartzose fine- and very fine-grained sandstone, weakly cemented, partly cross-bedded, with rare thin dark shale interbeds (sample 7). Thickness $0.35 \mathrm{~m}$.

Bed 4. Greyish-yellow fine- and very fine-grained quartzose sandstone, gradually coarsening upwards. The sandstone is sometimes weakly cross-bedded and contains few $1-2 \mathrm{~cm}$ thick shale interbeds (samples $8-11)$. Thickness $1.20 \mathrm{~m}$.

A

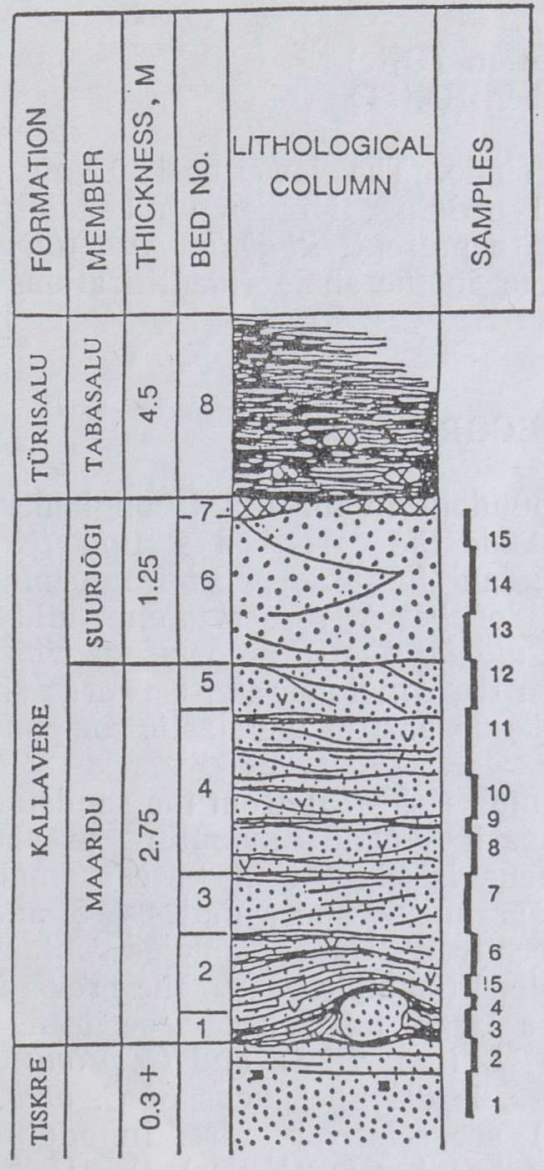

B

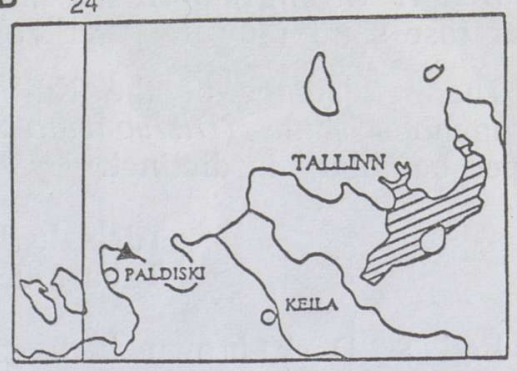

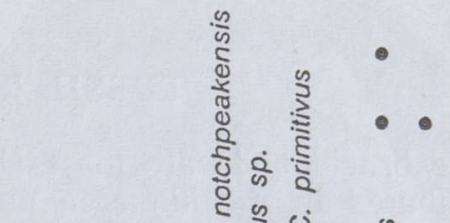

焉

空

के

象

อิ (⿻) D. ह के 3

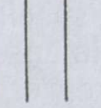

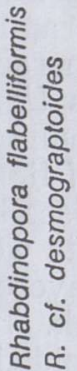

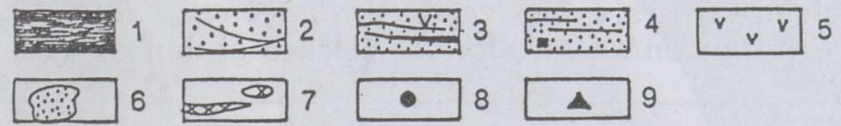

Fig. 1. Cambrian-Ordovician boundary beds in the Pakri Cape section: conodont and graptolite distribution $(A)$ and location scheme $(B)$. Legend: 1 , kerogenous shale; 2 , cross-bedded quartzose sandstone; 3 , quartzose sandstone intercalated with kerogenous shale; 4 , quartzose siltstone with clay interbeds; 5 , lingulate brachiopod debris; 6 , sandstone boulders; 7 , pyrite concretions and lenses; 8 , graptolite occurrences; 9 , location of the studied section. 
Bed 5. Brownish-yellow quartzose fine-grained sandstone, occasionally cross-bedded (sample 12). In general appearance this bed is transitional between the Maardu and Suurjõgi members. Thickness $0.35 \mathrm{~m}$.

\section{Suurjõgi Member $\left(\mathrm{O}_{1} \mathrm{k} \mathrm{IS}\right)$}

Bed 6. Yellowish-brown medium- to fine-grained cross-bedded sandstone with very rare tiny shell fragments of lingulate brachiopods (samples 13-15). Thickness $1.10 \mathrm{~m}$.

Bed 7. Strongly pyritized sandstone lenses in medium- to fine-grained quartzose sand ("pyrite layer"). Thickness $0.15 \mathrm{~m}$.

The sandstones of the Kallavere Formation are overlain by dark kerogenous shale (Dictyonema Shale) of the Türisalu Formation. The upper boundary is distinct.

\section{Türisalu Formation $\left(\mathrm{O}_{1} \mathrm{tr}\right)$}

Tabasalu Member $\left(\mathrm{O}_{1}\right.$ trT)

Bed 8. Dark brown kerogenous shale. The lowermost $0.5 \mathrm{~m}$ are characterized by indistinct horizontal bedding. Higher up bedding is almost missing; conchoidal fractures are present. Rhabdinopora flabelliformis and $R$. cf. desmograptoides occur in the shale (identifications by D. Kaljo). Thickness $4 \mathrm{~m}$.

\section{FOSSIL RECORD}

Lingulate brachiopods are most abundant in the basal conglomerate lenses distributed in a wide area outside the described section (Nemliher \& Puura, 1996). Among the abundant lingulate shell fragments in the conglomerate matrix, rare valves of better preservation could be identified as Ungula convexa and Ungula ingrica. Fragments of Ungula were also found in some pebbles within the conglomerate. Upwards shell fragments of lingulate brachiopods make up part of the clastic component of the rock (see below).

Conodonts were studied from 13 samples (3-15) from the sandstones of the Kallavere Formation (Fig. 1), each sample amounting to about $2 \mathrm{~kg}$ of rock. The number of specimens is highest in lower samples: sample 3 yielded several hundreds of specimens, and samples 4,5 , and 6 yielded 60,90 , and 25 specimens, respectively. Upper samples contained only from 2 to 16 specimens per sample. In samples $3-6$, the prevailing genus Cordylodus is represented by a large number of specimens of C. proavus Müller (P1. I, fig. 9; P1. II, figs. 1-3) and C. primitivus Bagnoli, Barnes et Stevens (P1. I, figs. 7, 8). Specimens of C. andresi Viira et Sergeyeva (P1. I, figs. 1-6) are relatively rare. In addition, samples 3-6 yielded Eoconodontus notchpeakensis (Miller) (P1. II, figs. 4,5 ) and sample 3 yielded very rare Westergaardodina bicuspidata Müller (P1. II, fig. 9) and Proconodontus rotundatus (Druce et Jones) (P1. II,

\section{PLATE I}

Figs. 1-6. Cordylodus andresi Viira et Sergeyeva. 1-5, rounded specimens Cn 1509Cn 1513, sample $3, \times 184, \times 160, \times 152, \times 168, \times 192$. 6, compressed specimen $C_{n} 1514$, sample $6, \times 184$.

Figs. 7, 8. Cordylodus primitivus Bagnoli, Barnes et Stevens. Rounded specimens Cn 1515, Cn 1516. 7, sample $6, \times 192$. 8, sample 3 , $\times 120$.

Fig. 9. Cordylodus proavus Müller. Compressed specimen Cn 1520 , sample $5, \times 120$. 
PLATE 1






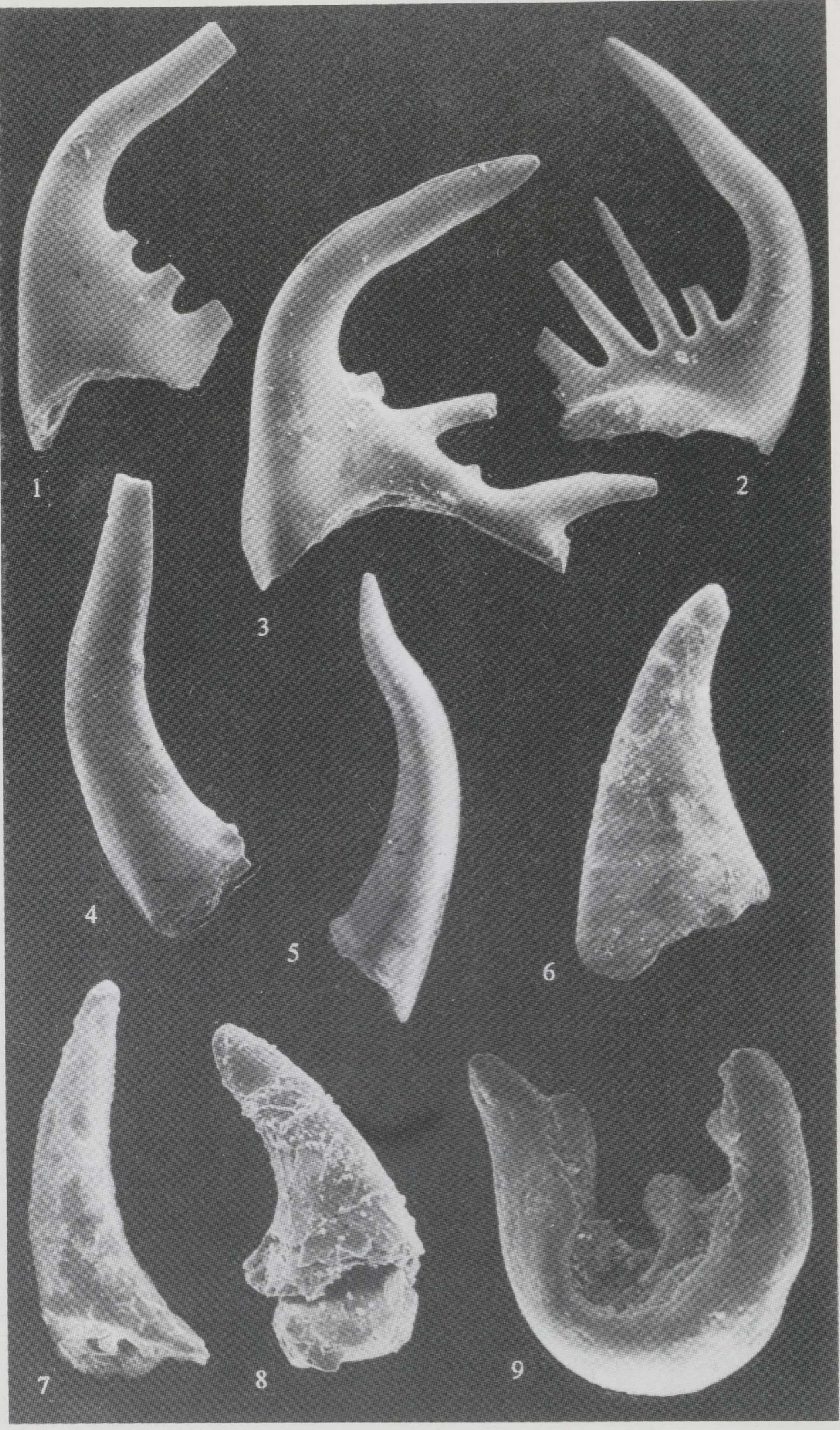


figs. $6-8$ ). The conodonts from samples $3-6$ are of yellowish-brown colour. In these samples, especially in sample 3 , some specimens of Cordylodus show a series of growth lines subparallel to the basal margin, some other specimens have a cusp with the anterior bending of the uppermost part (somewhat similar to the posterior keel). These features are characteristic of very early euconodonts. Recently it was established that $C$. primitivus is a junior synonym of $C$. andresi Viira et Sergeyeva (Ross et al., 1993; Szaniawski \& Bengtson, 1993). Still, in the Pakri Cape section these two species can be distinguished by the presence of white matter in the uppermost part of the cusp (C. primitivus) or its absence (C. andresi).

Samples $7-11$ yielded poorly preserved conodonts, mostly white and semi-opaque broken specimens of Cordylodus; C. proavus (samples 8, 9, $10), C$. primitivus, $P$. rotundatus (sample 10 ), and $E$. notchpeakensis (sample 10) were identified. Sample 12 from the Maardu Member and samples $13-15$ from the Suurjõgi Member did not yield conodonts.

In this section the sandstone part with conodonts (samples 3-11) corresponds to the $C$. proavus Zone. It should be noted that among more than ten sections studied in northern Estonia, the Pakri Cape section is the only one where the Suurjõgi Member does not yield conodonts (Kaljo et al., 1986, 1988; Mens et al., 1989). Usually, the Suurjõgi Member has yielded the conodonts of the $C$. angulatus Zone or the $C$. lindstromi and C. angulatus zones (Kaljo et al., 1986, 1988), and occasionally even those of the $C$. proavus Zone.

One specimen of Hadimopanella sp. was found from the heavy mineral fraction of sample 4. The sclerites of Hadimopanella, previously known in Estonia from the Upper Cambrian Tsitre Formation of the Turjekelder section (Märss, 1988) and recently recognized as fragments of scleritome of palaeoscolecid worms (Hinz et al., 1990) have been reported from the Cambrian and Ordovician rocks all over the World (recent review in Müller \& Hinz-Schallreuter, 1993).

\section{GRAIN SIZE AND DISTRIBUTION OF SKELETAL FRAGMENTS}

A distinct change in grain size of the clastic component is one of the main criteria for the subdivision of the Kallavere Formation into the Maardu and Suurjõgi members in northern Estonia (Хейнсалу, 1987). As this change can be clearly observed in the studied section, the same subdivisions can be distinguished on the Pakri Peninsula (Table 1).

The Maardu Member is mostly represented by very fine-grained $(0.05-0.1 \mathrm{~mm})$ and fine-grained $(0.1-0.25 \mathrm{~mm})$ sand, which together make up $75-98 \%$ of the whole clastic material with the predominance of the former. About $94-96 \%$ of the rock of the Suurjõgi Member are fineto medium-grained $(0.25-0.5 \mathrm{~mm})$ sand dominated by fine sand.

Although the grain size of the clastic component increases gradually through the upper part of the Maardu Member (Table 1, samples 11-12), the boundary between the two members is distinct.

\section{PLATE II}

Figs. 1-3. Cordylodus proavus Müller. Rounded specimens Cn 1517-Cn 1519, sample 5, $\times 96, \times 136, \times 120$.

Figs. 4, 5. Eoconodontus notchpeakensis (Miller). Specimens Cn 1521, Cn 1522, sample 3, $\times 120$.

Figs. 6-8. Proconodontus rotundatus (Druce et Jones). Specimens Cn 1523-Cn 1525. 6,7 , sample 3.8 , sample $10.6,8, \times 192 ; 7, \times 144$.

Fig. 9. Westergaardodina bicuspidata Müller. Specimen Cn 1526, sample 3, $\times 296$. 
Grain-size distribution of terrigenous and bioclastic components

\begin{tabular}{|c|c|c|c|c|c|c|}
\hline \multirow{2}{*}{ Samples } & \multicolumn{3}{|c|}{ Grain-size fractions ( $\mathrm{mm}$ ) of the } & \multicolumn{3}{|c|}{$\frac{\text { terrigenous }}{\text { bioclastic }}$ material, $\%$} \\
\hline & $1.0-0.5$ & $0.5-0.25$ & $0.25-0.1$ & $0.1-0.05$ & $0.05-0.01$ & $<0.01^{\prime}$ \\
\hline \multicolumn{7}{|l|}{ Suurjõgi Member } \\
\hline \multirow{2}{*}{ Pa-93-15 } & 0.18 & 22.28 & 74.05 & 2.63 & 0.26 & 0.60 \\
\hline & - & - & - & - & - & \\
\hline \multirow{2}{*}{$\mathrm{Pa}-93-14$} & 0.26 & 20.02 & 75.96 & 1.73 & 0.49 & 1.54 \\
\hline & - & - & - & - & - & \\
\hline \multirow{2}{*}{ Pa-93-13 } & 0.36 & 20.62 & 73.34 & 3.23 & 0.96 & 1.49 \\
\hline & - & - & - & - & - & \\
\hline \multicolumn{7}{|l|}{ Maardu Member } \\
\hline \multirow{2}{*}{$\mathrm{Pa}-93-12$} & - & 0.04 & 83.25 & 14.74 & 1.32 & 0.65 \\
\hline & - & - & - & - & - & \\
\hline \multirow{2}{*}{$\mathrm{Pa}-93-11$} & - & 0.019 & 58.66 & 36.62 & 2.94 & 0.43 \\
\hline & - & 0.002 & 0.35 & 0.86 & 0.12 & \\
\hline \multirow[t]{2}{*}{$\mathrm{Pa}-93-10$} & - & 0.03 & 39.89 & 47.71 & 11.75 & 0.40 \\
\hline & - & - & 0.10 & - & 0.12 & \\
\hline \multirow{2}{*}{$\mathrm{Pa}-93-9$} & - & 0.01 & 36.3 & 54.06 & 8.75 & 0.57 \\
\hline & - & - & 0.1 & 0.16 & 0.05 & \\
\hline \multirow{2}{*}{$\mathrm{Pa}-93-8$} & - & 0.009 & 33.38 & 55.87 & 9.72 & 0.69 \\
\hline & - & 0.001 & 0.1 & 0.17 & 0.06 & \\
\hline \multirow[t]{2}{*}{$\mathrm{Pa}-93-7$} & - & 0.03 & 49.79 & 43.69 & 5.63 & 0.69 \\
\hline & - & - & 0.15 & - & 0.017 & \\
\hline \multirow[t]{2}{*}{$\mathrm{Pa}-93-6$} & - & 0.04 & 22.38 & 62.22 & 14.39 & 0.64 \\
\hline & - & - & 0.06 & 0.19 & 0.08 & \\
\hline \multirow{2}{*}{$\mathrm{Pa}-93-5$} & 0.01 & 0.024 & 17.87 & 64.53 & 16.11 & 0.72 \\
\hline & - & 0.006 & 0.36 & 0.19 & 0.18 & \\
\hline \multirow[t]{2}{*}{$\mathrm{Pa}-93-4$} & - & 0.017 & 22.83 & 51.58 & 16.00 & 8.86 \\
\hline & - & 0.003 & 0.39 & 0.16 & 0.16 & \\
\hline \multirow[t]{2}{*}{$\mathrm{Pa}-93-3$} & - & 0.11 & 33.09 & 53.61 & 9.9 & 1.80 \\
\hline & - & 0.02 & 0.57 & 0.7 & 0.2 & \\
\hline \multicolumn{7}{|l|}{ Tiskre Formation } \\
\hline \multirow{2}{*}{$\mathrm{Pa}-93-2$} & - & 0.02 & 0.43 & 29.25 & 69.14 & 1.16 \\
\hline & - & 一 & - & - & - & \\
\hline \multirow[t]{2}{*}{$\mathrm{Pa}-93-1$} & 0.01 & 0.01 & 1.43 & 47.75 & 50.42 & 0.38 \\
\hline & - & - & - & - & - & \\
\hline
\end{tabular}

* bioclastic component not analysed;

- not detected.

In the Kallavere Formation the bioclastic component is mainly represented by phosphatic skeletal fragments of lingulate brachiopods and scarce conodont fragments. In the Pakri Cape section the phosphatic debris has been recorded only from the Maardu Member (samples 3-11), whereas its content exceeds $1 \%$ of the total rock only in samples 3 and 11 (Table 1). 
The skeletal debris consists predominately of light brown, poorly rounded fragments of lingulate brachiopods. In the lower beds of the section (samples 3 and 4 ) some fragments are covered with phosphatic films. The Suurjõgi Member and the upper part of the Maardu Member (samples 12-15) did not yield skeletal debris. The distribution of the debris by grain size is shown in Table 1 .

\section{MINERALOGY}

\section{Optical microscopy of the very fine sand fraction}

Light and heavy minerals of the very fine sand fraction $(0.1-0.05 \mathrm{~mm})$ were separated in a heavy liquid (bromoform, $\varrho=2.88 \mathrm{~g} / \mathrm{cm}^{3}$ ) and studied by optical microscopy using immersion liquids. The results are presented in Table 2 according to the counting sclieme recommended by Viiding (Вийдинг, 1976). Altogether 13 samples from the Kallavere Formation and two samples from the underlying Tiskre Formation were studied (Fig. 1, Table 2).

The light mineral suite is mostly composed of allogenic minerals represented predominantly by quartz, feldspars, and very rare flacks of muscovite. Among the authigenic minerals (generalized as one group, Table 2), gypsum occurs in large amounts in two samples of the Suurjõgi Member, reaching nearly 60 and $40 \%$ in samples 13 and 14 , respectively. Other samples yield rare grains of glauconite (samples 7, 8, 13 , and 14) or carbonate minerals (samples 5 and 15).

Quartz, the most abundant mineral among sand grains of the Kallavere rocks, is mostly characterized by rounded, more rarely well-rounded monocrystalline non-undulatory grains. The number of undulatory and polycrystalline grains is limited. The feldspar fraction, mostly K-feldspars, ranges from 2 to $10 \%$, but is usually between 3 and $7 \%$. Two kinds of feldspar grains are present: rounded detrital grains weathered to various degrees and those overgrown with fresh authigenic K-feldspar exhibiting rhombic faces. About half of feldspar grains in the Maardu Member are surrounded by a thin (less than $30 \mu \mathrm{m}$ ) fragmentary overgrowth. In the grains from the Suurjögi Member overgrowths are thicker $(30-50 \mu \mathrm{m})$ and commonly continuous around the detrital core; grains of that kind constitute about $70 \%$ of feldspars in this member. This phenomenon has also been observed in the rocks of the Kallavere Formation, particularly in the Suurjõgi Member in other localities, such as Ulgase, Mäekalda, and Saka (Mens et al., 1989; Хейнсалу et al., 1987, 1991).

The heavy fraction rarely exceeds $1 \%$ (Table 2). It is composed of allogenic (detrital) and authigenic minerals; the authigenic minerals prevail in the basal and top layers of the Kallavere Formation. In the group of allogenic heavy minerals, opaque and transparent minerals occur in almost equal quantities, whereas micaceous minerals (mainly muscovite) are uncommon.

Among opaque minerals (including leucoxene frequently occurring in detrital form), ilmenite prevails, particularly in the rocks of the Suurjõgi Member. Magnetite is lacking throughout the Kallavere Formation.

Among transparent allogenic heavy minerals zircon, tourmaline, and titano-minerals are common, but their ratio varies greatly. However, titano-minerals (represented mainly by rutile) amounting to $2-19 \%$ are associated neither with a particular rock type nor stratigraphical level. The general pattern known for the Kallavere Formation implies the prevalence of zircon over tourmaline, especially in the Suurjõgi Member 





(Mens et al., 1989; Хейнсалу et al., 1987, 1991). In the Pakri Cape section, the prevalence of tourmaline over zircon in the lower part of the Maardu Member (samples 3-6) was recorded for the first time. The occurrence of medium-stable minerals (garnet, apatite) is variable and does not reflect certain stratigraphical dependence. It should be noted that apatite is not common in the Suurjõgi Member.

The finds of unstable minerals are random and very rare. They occur only in the lower part of the Maardu Member and consist of strongly altered pyroxene and amphibole.

Authigenic heavy minerals are represented by pyrite and Fe-oxides and hydroxides throughout the studied section. Anatase and phosphate minerals are characteristic of the lower part of the Maardu Member. The phosphatic rims around the detrital grains of ilmenite, tourmaline, rutile, zircon, and occasionally quartz in the light fraction are observed only in the Maardu Member. Carbonate minerals occur sporadically and, at the topmost level of the formation, in considerable amounts.

\section{XRD of clay minerals}

Qualitative and semiquantitative study of the mineralogical composition of the $<2 \mu \mathrm{m}$ fraction was carried out by X-ray diffraction analysis (XRD) on a DRON-0.5 diffractometer using Mn-filtered Fe-K $\alpha$ radiation. Air-dried, glycolated, and heated $\left(500^{\circ} \mathrm{C}\right)$ oriented samples were prepared for qualitative clay mineral identification. The relative content of clay minerals was estimated semiquantitatively by using empirical correction factors of XRD peak intensities based on earlier clay mineral studies at the X-ray laboratory of the Institute of Geology, University of Tartu. The illite, illite-smectite, smectite, chlorite, and kaolinite peak intensities were corrected by factors $0.55,0.16,0.09,0.45$, and 1.0 , respectively.

The last five clay minerals comprise up to $0.5 \mathrm{wt} \%$ of the whole rock (Fig. 2). The main components of the clay material in sandstone pores are illite and illite-smectite making up from 80 to $100 \%$ of the cement. Alongside with normal illite, a degraded form was also distinguished, displaying an asymmetry of the $d(001)=10.1 \AA$ reflection towards the low angle side; illite-smectite has basal (001) reflections according to $d$-spacing $10.45-11.0 \AA$.

In the Kallavere Formation the illite content decreases and the illitesmectite content increases gradually from base to top. These changes correlate to the general trend of increase in grain size.

At some levels (Fig. 2) smectite was identified. It is represented by a quite well crystallized (Thorez, 1976) variety having $d(001)=12.8-13.0 \AA$ in normal and $d(001)=17.4-17.5 \AA$ in glycolated samples.

Chlorite occurs in small amounts (up to $18 \%$ ) throughout the section. It seems to be a rather $\mathrm{Mg}$-rich detrital variety displaying a quite high basal reflection at $14.2-14.4 \AA$ and about equal to the (002) reflection intensity (Thorez, 1976). This variety differs from the Fe-rich varieties described from the Cambrian sandstone pores in Latvia (Апините, 1971) and Estonia (Пиррус, 1970). The asymmetry of the (002) reflection in an air-dried sample and structure contraction after heating $\left(500^{\circ} \mathrm{C}\right)$ suggest that the detrital chlorite, which can be easily destroyed by changes in the chemical environment (Velde, 1985), has been somewhat degraded by weathering processes in the outcrop.

Kaolinite occurs at certain levels (Fig. 2); its amount does not usually exceed $10 \%$ of the $<2 \mu \mathrm{m}$ fraction. The kaolinite content is highest at the top of the Tiskre Formation and in the basal Maardu Member (samples $3-6)$. For most of the kaolinite in the lower part of the Maardu Member, diagenetic origin is suggested, because it occurs at the levels closely

2 Eesti TA Toimetised. G 11996 


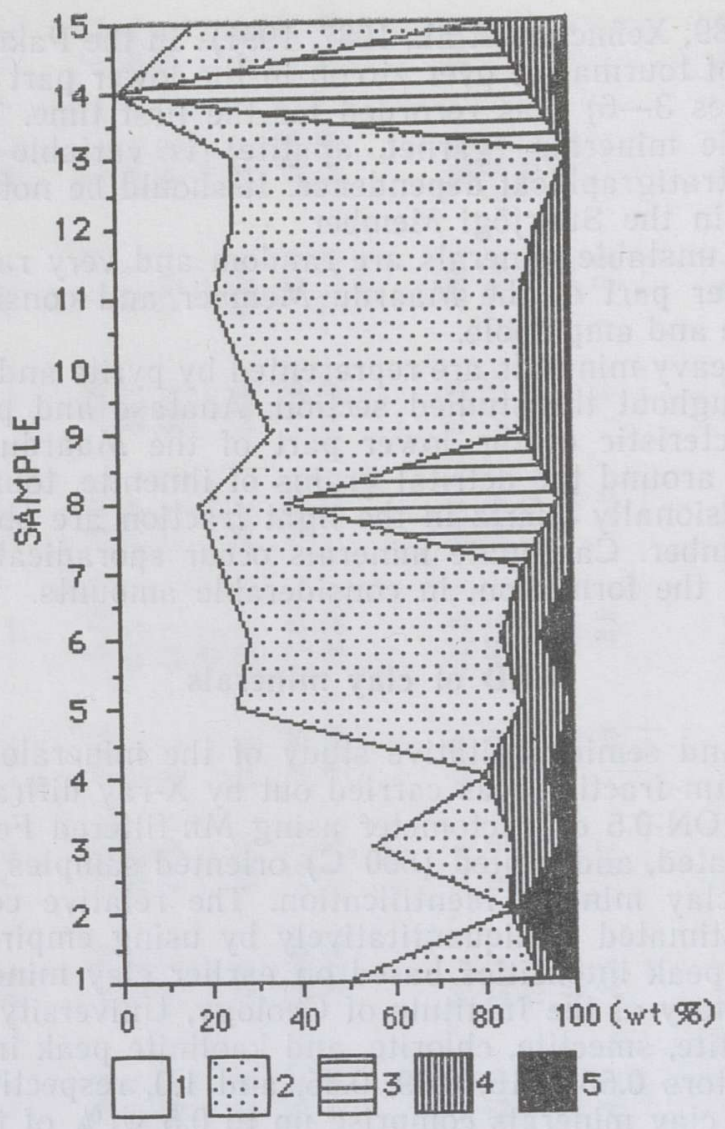

Fig. 2. Mineral composition of clay fraction $(<2 \mu \mathrm{m})$ in the Pakri Cape section. Legend: 1, illite; 2, illite-smectite; 3 , smectite; 4 , chlorite; 5 , kaolinite.

related to the kerogenous shale layer. According to Curtis (1987), the dissolution of source minerals favoured by acidic conditions and the presence of relict organic matter is followed by a $\mathrm{pH}$ rise due to acid consumption. This would lead to kaolinite precipitation during diagenesis but kaolinite is moderately ordered, which is not typical of authigenic kaolinite (Chamley, 1989).

An abrupt change in the clay mineral content occurs at the boundary of the Tiskre and Kallavere formations. The top of the Tiskre Formation is characterized by a relatively high content of kaolinite, low chlorite content, and well-crystallized illite; the latter is characteristic of repeated wettingdrying processes (Srodon \& Eberl, 1984). Such a mineralogy is interpreted as resulting from weathering processes during a long hiatus in sedimentation.

\section{DISCUSSION AND CONCLUSIONS}

According to current conventional use of the conodont zonation, the lower boundary of the Pakerort Stage is tentatively defined by the appearance of the genus Cordylodus, i.e. with the base of the Cordylodus andresi Zone (Kaljo et al., 1986; Männil, 1990).

In the studied Pakri Cape section, the only conodont zone established is the Cordylodus proavus Zone corresponding to the lower part of the 
Maardu Member (samples 3-6). Owing to the scarcity and poor preservation of conodonts in the upper beds of the Maardu Member (samples 7 - 11), the upper boundary of the $C$. proavus Zone and the boundaries of younger conodont zones cannot be defined with confidence in this section. At the level of a change in conodont abundance and preservation, in the lower part of the Maardu Member (between samples 6 and 7), notable differences in the depositional conditions and mineralogical compositions are observed. Most likely they reflect increasing hydrodynamic activity and changes in bottom topography of the sedimentary basin.

The lenses of the basal conglomerate found in about $200 \mathrm{~m}$ of the section (Nemliher \& Puura, 1996) yield lingulate brachiopods Ungula convexa and Ungula ingrica known from the Upper Cambrian of Baltoscandia (Попов \& Хазанович, 1989; Puura \& Holmer, 1993). Conodonts and acritarchs have not been studied from these conglomerate lenses as yet.

Considering the presently known fossil evidence from the Pakri Cape section and knowledge on the biostratigraphy and distribution of the Cambrian-Ordovician boundary beds of Estonia (Kaljo et al., 1986; Mens et al., 1993), three possible options for the age of the basal conglomerate should be considered: the conglomerate may be correlative either to the Proconodontus Subzone of the Westergaardodina Zone, the Cordylodus andresi Zone or the $C$. proavus Zone.

The deposits of the Proconodontus Subzone, represented by the Tsitre Formation, are known to occur in restricted areas east of Tallinn (Попов \& Хазанович, 1989). Still, we cannot exclude the possibility that in the Ulgase section the conodont assemblage from the lower part of the Kallavere Formation belongs to this subzone (Хейнсалу et al., 1987; Mens et al., 1993). The upper part of the range of Ungula convexa and the lowermost part of the range of Ungula ingrica are tentatively correlative to this subzone.

The deposits of the $C$. andresi Zone are widely distributed in northern Estonia. They are found in the Ulgase, Valkla, Toolse, and Vihula sections east of Tallinn, in the M-9 core south of Maardu, and in the Kidaste core on Hiiumaa Island (Kaljo et al., 1986; Mens et al., 1993). On the other hand, the Cordylodus andresi Zone is missing in stratigraphically less complete sections in Tallinn and westwards (Kaljo et al., 1988; Mens et al., 1989, 1993; Попов \& Хазанович, 1989), including the studied Pakri Cape section.

As discussed above, the beds of the Maardu Member above the basal conglomerate in the Pakri Cape section yield the conodonts of the Cordylodus proavus Zone, i.e., the conglomerate formation might have occurred before or during the $C$. proavus time. At the present stage of the study, the question about the existence of the two oldest conodont zones in the Pakri Peninsula sections remains open.

To sum up, with regard to the current concept of the Pakerort Stage, the Pakri Cape section, where only the $C$. proavus Zone can be defined with confidence, is biostratigraphically not representative of the lower part of the Pakerort Stage. Further studies of the sections on the Pakri Peninsula are necessary for estimating the stratigraphical extent of the Pakerort Stage in its stratotype area.

\section{ACKNOWLEDGEMENTS}

We acknowledge the help of Prof. Dimitri Kaljo with identifying graptolites, Ursula Moldov is thanked for scanning electron microscopy, Jüri Nemliher for computer work, and Malle Sommer for preparing the figures. The research was supported by grant No. 318 of the Estonian Science Foundation. 


\section{REFERENCES}

Chamley, H. 1989. Clay Sedimentology. Springer, Berlin.

Curtis, C. 1987. Mineralogical consequences of organic matter degradation in sediments. - In: Leggett, J. K., Zuffa, G. G. (eds.). Marine Clastic Sedimentology. Graham \& Trotman, London, 108-123.

Hinz, I., Kraft, P., Mergl, M., Müller, K. J. 1990. The problematic Hadimopanella, Kaimenella, Milaculum and Utahphospha identified as sclerites of Palaeoscolecida. Lethaia, 23, 217-221.

Kaljo, D., Borovko, N., Heinsalu, H., Khazanovitch, K., Mens, K., Popov, L., Sergeyeva, S., Sobolevskaya, R., Viira, V. 1986. The Cambrian-Ordovician boundary in the Baltic-Ladoga clint area (North Estonia and Leningrad region, USSR). - Proc. Acad. Sci. ESSR. Geol., 35, 3, 97-108.

Kaljo, D., Heinsalu, H., Mens, K., Puura, I., Viira, V. 1988. The Cambrian-Ordovician boundary beds at Tõnismägi, Tallinn, North Estonia. - Geol. Mag., 125, 4, $457-463$.

Mens, K., Viira, V., Paalits, I., Puura, I. 1989. Cambrian-Ordovician boundary beds at Mäekalda (Tallinn, North Estonia). - Proc. Estonian Acad. Sci. Geol., 38, 3, $101-111$.

Mens, K., Viira, V., Paalits, I., Puura, I. 1993. Upper Cambrian biostratigraphy of Estonia. - Proc. Estonian Acad. Sci. Geol., 42, 4, 148-159.

Männil, R. 1990. The Ordovician of Estonia. - In: Kaljo, D., Nestor, H. (eds.). Field Meeting Estonia 1990. An Excursion Guidebook. Tallinn, 11-20.

Märss, T. 1988. Early Palaeozoic hadimopanellids of Estonia and Kirgizia. - Proc. Acad. Sci. ESSR. Geol., 37, 1, 10-17.

Müller, K., Hinz-Schallreuter, I. 1993. Palaeoscolecid worms from the Middle Cambrian of Australia. - Palaeontology, 36, 3, 549-592.

Nemliher, J., Puura, I. 1996. Upper Cambrian basal conglomerate of the Kallavere Formation on the Pakri Peninsula, NW Estonia. - Proc. Estonian Acad. Sci. Geol., $45,1,1-8$.

Puura, I., Holmer, L. 1993. Lingulate brachiopods from the Cambrian-Ordovician boundary beds of Sweden. - Geol. Fören. Stockholm Förh., 115, 3, 215-237.

Raymond, P. E. 1916. Expedition to the Baltic Provinces of Russia and Scandinavia. Part 1. The correlation of the Ordovician strata of the Baltic Basin with those of Eastern North America. - Bulletin of the Museum of Comparative Zoology at Harvard College, 56, 3, 179-286.

Ross, R. J., Jr., Hintze, L. F., Ethington, R. L., Miller, J.F., Taylor, M. E., Repetski, J. E. 1993. The Ibexian Series (Lower Ordovician), a replacement for "Canadian Series" in North American chronostratigraphy. Chapter B. - In: Taylor, M. E. (ed.). Paleozoic Biostratigraphy of the Great Basin, Western United States. Open-File Report 93-598, 1-75.

Srodon, J., Eberl, D. D. 1984. Illite. - In: Bailey S. W. (ed.). Micas. Mineralogical Society of America. Reviews in Mineralogy, 13, 495-544.

Szaniawski, H., Bengtson, S. 1993. Origin of euconodont elements, - J. Paleont., 67, 4, $640-654$.

Thorez, J. 1976. Practical Identification of Clay Minerals. Institute of Mineralogy, Liège State University, Dison.

Velde, B. 1985. Clay Minerals. A Physical-Chemical Explanation of Their Occurrence. Elsevier, Amsterdam.

Апините И. 1971. Глинистое вещество в кембрийских отложениях Латвни. - Изв. АН ЭССР. Хим. Геол., 20, 3, 232-238.

Вийдинг Х. 1976. Об интерпретации данных минералогического анализа. - In: Нарбутас В. (ed.). Методика и интерпретация результатов минералогических и геохимических исследований. Мокслас, Вильнюс, 53-59.

Мююрисепп К. К. 1958. Характеристика нижней границы пакерортского горизонта от мыса Пакерорт до реки Сясь. - Тр. Ин-та геол. АН ӘССР, ІІІ, 55-79.

Мююрисепп К. К. 1960. Литостратиграфия пакерортского горизонта в Эстонской ССР по данным обнажений. - Тр. Ин-та геол. АН ЭССР, V, 37-45. 
Пиррус Э. 1970. Закономерности распределения глинистых минералов в вендских и кембрийских отложениях Восточной Эстонии. - Изв. АН ЭССР. Хим. Геол., 19, 4, 322-333.

Попов Л. Е., Хазанович К. Қ. 1989. Лингулаты (беззамковые брахиоподы с фосфатнокальциевой раковиной). - In: Никитин И. (ed.). Опорные разрезы и стратиграфия кембро-ордовикской фосфоритоносной оболовой толщи на северо-западе Русской платформы. Наука, Ленинград, 96-136.

Хейнсалу Х. 1987. Литостратиграфическое расчленение тремадокских отложений Северной Эстонии. - Изв. АН ЭССР. Геол., 36, 2, 66-78.

Хейнсалу Х., Вийра В., Менс К., Оя Т., Пуура И. 1987. Кембрийско-ордовикские пограничные отложения разреза Юлгазе, Северная Эстония. - Изв. АН ЭССР. Геол., 36, 4, 154-165.

Хейнсалу Х., Қурвитс Т., Оя Т. 1991. Литолого-минералогическая характеристика стратотипического разреза раннуской пачки $\left(\epsilon_{3}-\mathrm{O}_{1} k l \mathrm{R}\right)$ в Сака II, Северо-Восточная Эстония. - Изв. АН Эстонии. Геол., 40, 1, 1-7.

\title{
KAMBRIUMI JA ORDOVIITSIUMI PIIRIKIHID PAKRI NEEME LÄBILŌIKES, LOODE-EESTI
}

Kaisa MENS, Heljo HEINSALU, Kalmer JEGONJAN, Tiia KURVITS, Ivar PUURA, Viive VIIRA

Pakri neeme läbilõike kambriumi ja ordoviitsiumi piiriintervall kuulub litostratigraafiliselt Kallavere kihistusse, mis on jaotatud Maardu ja Suurjõe kihistikeks.

Artiklis on toodud Kallavere kihistu paleontoloogilise ja mineraloogilise uurimise tulemused.

Uuritud läbilõikes algab kihistu Cordylodus proavus'e tsooni tasemel. Fossiilide vähese säilimuse või puudumise tôttu ei ole kihistu ülemise osa biostratigraafilist kuuluvust täpsemalt võimalik määrata. Kallavere kihistut iseloomustab väga väike biogeense komponendi sisaldus, turmaliini valdamine läbipaistvate raskete mineraalide rühmas ja laialdane kipsi levik Suurjõe kihistiku ülemises osas.

\section{КЕМБРИЙСКО-ОРДОВИКСКИЕ ПОГРАНИЧНЫЕ ОТЛОЖЕНИЯ В РАЗРЕЗЕ МЫСА ПАКРИ, СЕВЕРО-ЗАПАДНАЯ ЭСТОНИЯ}

\author{
Кайса МЕНС, Хельо ХЕИНСАЛУ, Калмер ЕГОНЯН, \\ Тийа КУРВИТС, Ивар ПУУРА, Вийве ВИиРА
}

В разрезе мыса Пакри кембрийско-ордовикский пограничный интервал сложен отложениями каллавереской свиты, состоящей из маардуской и суурйыгиской пачек. В статье дана минералогическая характеристика тонкопесчаной и пелитовой фракций пород каллавереской свиты. Палеонтологическое изучение позволяет заключить, что в этом разрезе каллавереская свита начинается на уровне конодонтовой зоны Cordylodus proavus. Верхняя половина каллавереской свиты из-за плохой палеонтологической представленности биостратиграфически не определена. 